\title{
Teaching NeuroImages: Cortical damage with leptomeningeal enhancement in neuromyelitis optica spectrum disorder
}

Hui Sun, MMe, and Lei Wu, MD

Neurology ${ }^{\circledR}$ 2018;91:e1087-e1088. doi:10.1212/WNL.0000000000006161
Correspondence

Dr. Wu

wlyingsh@163.com

Figure Neuroimaging (MRI) during the course of the disease

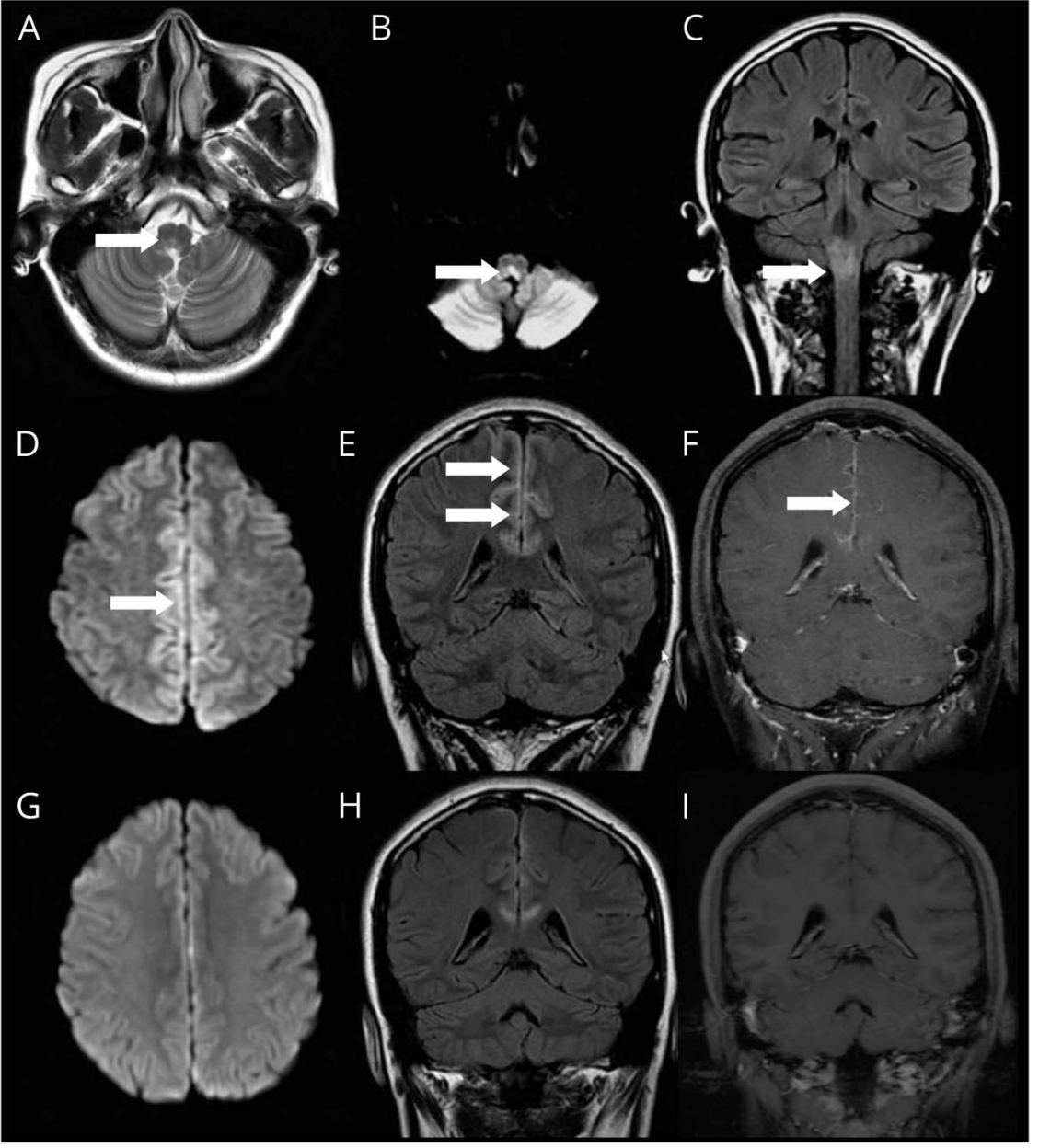

Axial T2-weighted images, diffusion-weighted imaging (DWI), and coronal fluid-attenuated inversion recovery (FLAIR) images (arrows; A-C) show medulla hyperintensity. DWI and corona FLAIR images show focal cortical hyperintensity (singular and double arrows; D-E) and leptomeningeal enhancement (F). The local foci improved after treatment (G-I).

A 27-year-old woman presented with headache, weakness, and numbness in both lower extremities for 2 weeks. Two years ago, she had refractory hiccups and vomiting with associated area postrema lesions on MRI (figure, A-C). Workup for infectious disease was negative. Serum aquaporin-4-immunoglobulin G was positive. Recent MRI showed cortical damage adjacent to the cerebral falx with leptomeningeal enhancement (figure, D-F).

\section{MORE ONLINE}

$\rightarrow$ Teaching slides

links.lww.com/WNL/ A665 
Treatment with immunoglobulin and high-dose methylprednisolone produced a significant improvement of the symptoms and the follow-up MRI (figure, G-I). This patient's case is unusual, as neuromyelitis optica spectrum disorders rarely involve the cortex and pia mater. ${ }^{1,2}$

\section{Author contributions}

Dr. Sun: conception, design, and writing the first manuscript. Dr. Wu: critical revision of manuscript for intellectual content and study supervision.

\section{Study funding}

No targeted funding reported.

\section{Disclosure}

The authors report no disclosures relevant to the manuscript. Go to Neurology.org/N for full disclosures.

\section{References}

1. Kim W, Lee JE, Kim SH, et al. Cerebral cortex involvement in neuromyelitis optica spectrum disorder. J Clin Neurol 2016;12:188-193.

2. Kim JE, Kim SM, Ahn SW, et al. Brain abnormalities in neuromyelitis optica.J Neurol Sci 2011;302:43-48. 


\section{Neurology}

\section{Teaching NeuroImages: Cortical damage with leptomeningeal enhancement in neuromyelitis optica spectrum disorder \\ Hui Sun and Lei Wu \\ Neurology 2018;91;e1087-e1088 \\ DOI 10.1212/WNL.0000000000006161}

This information is current as of September 10, 2018

\section{Updated Information \& Services}

References

Citations

Subspecialty Collections

Permissions \& Licensing

Reprints including high resolution figures, can be found at: http://n.neurology.org/content/91/11/e1087.full

This article cites 2 articles, 0 of which you can access for free at: http://n.neurology.org/content/91/11/e1087.full\#ref-list-1

This article has been cited by 1 HighWire-hosted articles: http://n.neurology.org/content/91/11/e1087.full\#\#otherarticles

This article, along with others on similar topics, appears in the following collection(s):

\section{All Headache}

http://n.neurology.org/cgi/collection/all_headache

Devic's syndrome

http://n.neurology.org/cgi/collection/devics_syndrome

MRI

http://n.neurology.org/cgi/collection/mri

Optic neuritis; see Neuro-ophthalmology/Optic Nerve

http://n.neurology.org/cgi/collection/optic_neuritis

Transverse myelitis

http://n.neurology.org/cgi/collection/transverse_myelitis

Information about reproducing this article in parts (figures,tables) or in its entirety can be found online at:

http://www.neurology.org/about/about_the_journal\#permissions

Information about ordering reprints can be found online:

http://n.neurology.org/subscribers/advertise

Neurology ${ }^{\circledR}$ is the official journal of the American Academy of Neurology. Published continuously since 1951, it is now a weekly with 48 issues per year. Copyright @ 2018 American Academy of Neurology. All rights reserved. Print ISSN: 0028-3878. Online ISSN: 1526-632X.

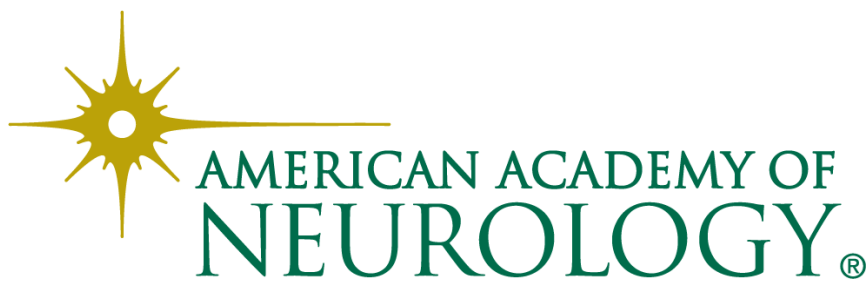

